\title{
Particle Size Distribution and Hydraulic Conductivity in Coastal Non-Agricultural Land in Gaza Coastal Plain
}

\author{
Jamal Safi ${ }^{1,2}$, Yasser El-Nahhal11,3*, Mohamed Safi ${ }^{1}$ \\ ${ }^{1}$ Environmental Protection and Research Institute (EPRI), Gaza, Palestine \\ ${ }^{2}$ Al-Azhar University, Gaza, Palestine \\ ${ }^{3}$ TheIslamic University of Gaza, Gaza, Palestine \\ Email: ^eprigaza@palnet.com,y_el_nahhal@hotmail.com
}

How to cite this paper: Safi, J., El-Nahhal, Y. and Safi, M. (2018) Particle Size Distribution and Hydraulic Conductivity in Coastal Non-Agricultural Land in Gaza Coastal Plain. International Journal of Geosciences, 9, 619-633.

https://doi.org/10.4236/ijg.2018.910037

Received: September 9, 2018

Accepted: October 23, 2018

Published: October 26, 2018

Copyright (c) 2018 by authors and Scientific Research Publishing Inc. This work is licensed under the Creative Commons Attribution International License (CC BY 4.0).

http://creativecommons.org/licenses/by/4.0/

\section{(c) (i) Open Access}

\begin{abstract}
Background: Particle size distribution and hydraulic conductivity of coastal no-agricultural lands are not available. This study characterized the particle size distribution and hydraulic conductivity on coastal non-agricultural land along the coastal plain of Gaza. Materials and Methods: Six soil profiles were digged along the coastal plain in Gaza Strip and soil samples were collected from $0-150 \mathrm{~cm}$ depth. Four soil plots around each site were used to determine the hydraulic conductivity using Infiltrometer method. Four particle size groups were identified, group $1(630 \mathrm{~nm})$, group $2(200 \mathrm{~nm})$, group $3(63 \mathrm{~nm})$ and group $4(20 \mathrm{~nm})$. Results: Dominancy of particle size group 2 was noticed in all sites followed by group 3. Groups 1 and 4 were less dominant in all sites. Hydraulic conductivity ranged from lower value 0.27 in the control soil plot in Khan Younis (site 1) to the highest value $1.76 \mathrm{~m} / \mathrm{s}$ in disturbed soil plot in Shakhejjlen (site 3) with regression coefficient (R2) range of 0.9725 0.997 indicating strong positive association. Conclusion: It can be concluded that the coastal non-agricultural land is sandy with various hydraulic conductivity values due to different particle size distribution. These data are useful to the scientific community around the world and will be helpful to speculate potential risk factors to life of ecosystem.
\end{abstract}

\section{Keywords}

Particle Size, Hydraulic Conductivity, Soil Disturbance, Coastal Land, Soil Profile, Ecosystem

\section{Introduction}

Particle size distribution in soil is an important soil property that characterizes 
water holding capacity, water movement and other physical and chemical properties of soil. The importance of soil particles emerged from the fact that it can determine the fate of many organic and inorganic chemicals in soil environment [1] [2] [3]. Clay fraction in soil plays an important role in the retention of organic and inorganic cations in soil layers [4]. A number of investigations [5] [6], revealed the ability of fine soil particles to retain higher concentrations of heavy metal than larger size fractions because the finer particles have a higher surface area per unit weight. Furthermore, the finest soil particles $(<10 \mu \mathrm{m})$ may be absorbed into human tissues [7] or re-suspended in the atmosphere by different mechanisms [8], creating environmental problem in cities [9]. So far, soil particle size can create a huge diversity of micro-pores that govern the movement of water and air in soil profile [10] [11] and have import roles in the ecosystem [12]. Large particle size creates larger pore-size, and consequently fast movement of air water molecules. On the hands, smaller particle size creates smaller pore-size or capillary pore size that retains water and increase water holding capacity of soil. So far, hydraulic conductivity in soil is directly connected with particles size distribution in soil profile. Several methods have been tested for determination of hydraulic conductivity; this included integrated global soil databases with land use/land cover databases and saturated hydraulic conductivity [13], pedotransfer functions [14], rainfall-induced seals [15] and influence of biochar [16]. These investigations provided valuable information that was applied in agricultural soils around the world. The abovementioned studies were limited to agricultural or forest lands. Particle size distribution, and hydraulic conductivity in coastal non-agricultural lands were poorly investigated or remains in the primary stages of investigation. The novelty of this study emerged from the fact that it targeted coastal not agricultural land and generate useful information to the environmental scientist around the world. The objectives of this investigation were to characterize the particle size distribution and hydraulic conductivity on coastal, non-agricultural lands along the coastal plain in Gaza Strip.

\section{Materials and Methods}

\subsection{Selection of Experimental Sites}

\section{Site Description}

Six sites were selected for digging soil profile along the rainfall gradients in Gaza strip. These site are Khan Younis (South, site 1), Bait Lahia (North, site 2), Gaza-Shakhejjlen (sites 3 \& 4), and Rafah sites ( 5 \& 6).

1) Khan Younis (Site 1)

It is located in the southern part of Gaza. It has the following GPS information $\left(\mathrm{N}, 31^{\circ} 26^{\prime} 37.56^{\prime \prime} ; \mathrm{E}, 34^{\circ} 21^{\prime} 37.35^{\prime \prime}\right)$. The area is about $2500 \mathrm{~m}^{2}$. It is a sandy soil. It is $400 \mathrm{~m}$ far away from Mediterranean Sea. No agricultural activities were running in the site during the past 10 years, but the site contains a lot of wild type 
weeds, plants and some trees. The surrounding area of the site contains fruit trees such as Gova, palm trees and other desert shrubs. The average rainfall is about 290 $\mathrm{mm}$, and far away from the site some vegetable cultivation. The information of this site was obtained from the Mayer of the city by personal communications.

2) Bait Lahia (Site 2)

Site II is located in Bait Lahia, the northern part of Gaza Strip. It has the following GPS information ( $\mathrm{N}, 31^{\circ} 33^{\prime} 55.14^{\prime \prime}$; E, 34 $\left.28^{\prime} 16.75^{\prime \prime}\right)$. The site is about 150 $\mathrm{m}$ a part from the sea. It is located in coastal area. The eastern part of the site has some agricultural activity with vegetable and greenhouse production. The historical information from the owner indicates that the land did not contain any agricultural waste, municipal or hazardous materials. The annual rainfall is about $433 \mathrm{~mm}$. The information of this site was obtained from the Land Owner Mr M abu Halema by personal communications.

3) Shakhejjlen area (Site $3 \& 4$ )

These sites are located in Shakhejjlen area, 650 meter far away from the sea sure. It has the following GPS information (N, 31 $29^{\prime} 0.89^{\prime \prime}$; E, 34 $\left.24^{\prime \prime} 3.08^{\prime \prime}\right)$. The history of the area is an agricultural land specified with fruit production such as grapes, fig, and little citrus trees. Big trees such as Tamarex are cultivated as boarder line trees among farms.

The annual rain fall in the area is $394 \mathrm{~mm}$. The history of the site indicates no hazardous waste dumpsite in the area in the past 10 year and the boarder trees, Tamarex are old trees. In this site two soil profiles were made, one directly under the stem of Tamarex and the second is 3 meters away from the stem. The information of this site was obtained from ministry of agriculture, PNA, un published results.

4) Rafah (Site $5 \& 6$ )

These sites are located in Rafah area, $3 \mathrm{~km}$ far away from the sea, Rafah area is the southern part of Palestine. It has the following GPS information (N, 31 ' 8 '38.74"; E, $\left.34^{\circ} 15^{\prime \prime} 35.19^{\prime \prime}\right)$. The site is sand dunes with no human activity except grazing. It has variety of wild type vegetation. The annual rain fall in the area is about 236 $\mathrm{mm}$. In this site two soil profiles were made, one directly under the stem and the second is 3 meters away from the stem. Moreover, the important data of all sites are summarized in Table 1 and their locations in Gaza Strip are presented in Figure 1 . The information of this site was obtained from municipality of Rafah city, PNA, unpublished results.

\subsection{Soil Sampling}

Six soil profiles were digged along $45 \mathrm{~km}$ in the coastal plain of Gaza Stip. Each soil profile has the following dimension $100 \times 200 \times 150 \mathrm{~cm}$ (Figure 1). Samples were collected from soil profile at both sites at of depths of $0-10,10-20,20$ 30,30 - 40, 40 - 50, 50 - 70, 70 - 90, $90-110,110-130$, and $130-150 \mathrm{~cm}$.

Soil samples were air dried sieved through $2 \mathrm{~mm}$ mish size to remove the gravels and big stones and storage in plastic containers at room temperature for further analysis. 
Table 1. Locations, distance, rainfall and GPS information of the sites.

\begin{tabular}{|c|c|c|c|c|c|}
\hline Site No. & Location & Distance from sea (m) & Rainfall (mm) & $\mathrm{N}$ & $\mathrm{E}$ \\
\hline 2 & Bait Lahia & 150 & 433 & $31^{\circ} 33^{\prime} 55.14^{\prime \prime}$ & $34^{\circ} 28^{\prime} 16.75^{\prime \prime}$ \\
\hline $3+4$ & Shakhejjlen & 650 & 394 & $31^{\circ} 29^{\prime} 0.89^{\prime \prime}$ & $34^{\circ} 24^{\prime} 3.08^{\prime \prime}$ \\
\hline 1 & Khan Younis & 400 & 290 & $31^{\circ} 26^{\prime} 37.56^{\prime \prime}$ & $34^{\circ} 21^{\prime} 37.35^{\prime \prime}$ \\
\hline $5+6$ & Rafah & 3000 & 236 & $31^{\circ} 18^{\prime} 38.74^{\prime \prime}$ & $34^{\circ} 15^{\prime} 35.19^{\prime \prime}$ \\
\hline
\end{tabular}

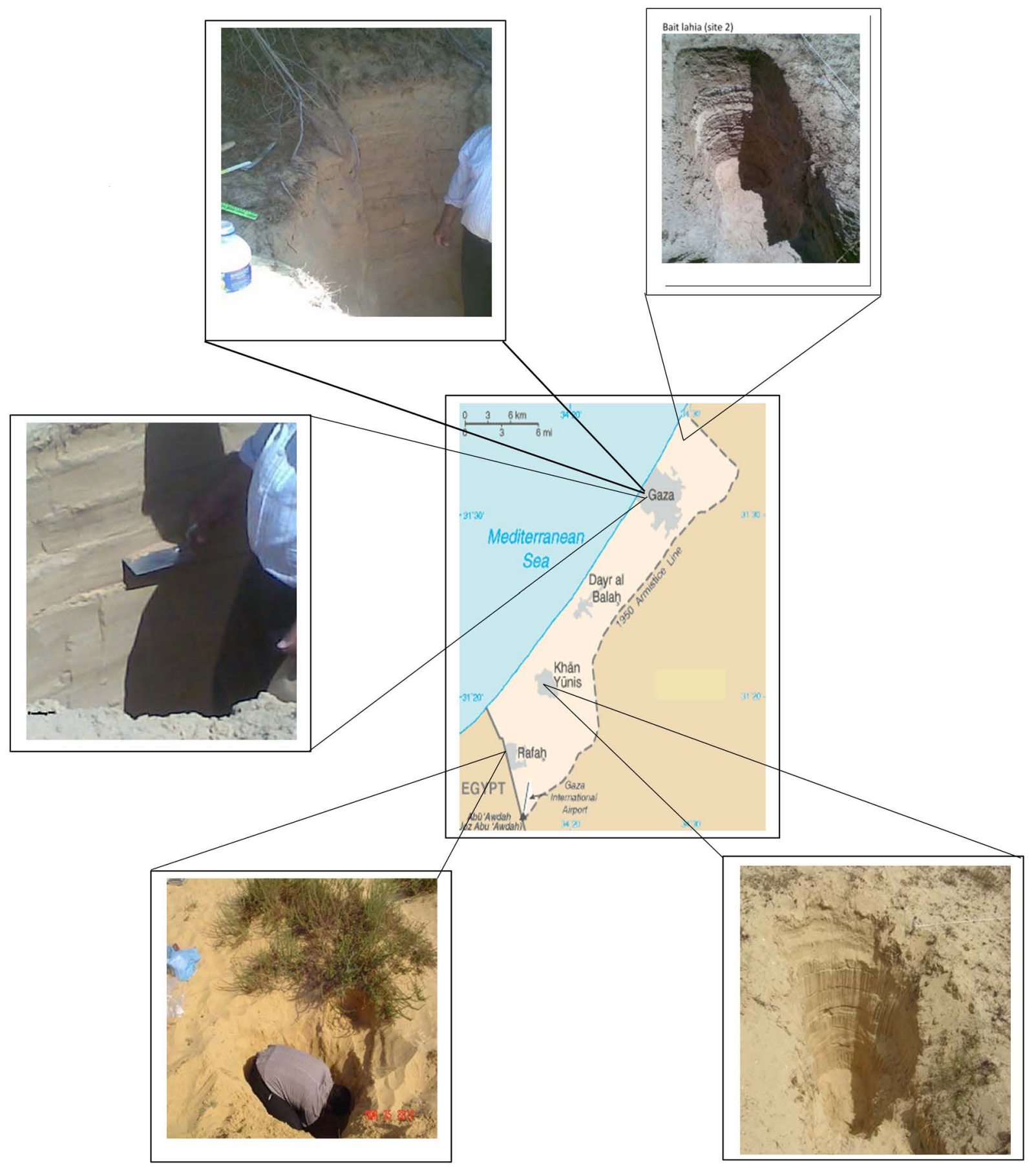

Figure 1. Soil profile photos and locations in Gaza Strip map. 


\subsection{Particle Size Distribution}

With modifications to the previously described procedures [17] [18], particle size distribution was determined. In this procedure ten $\mathrm{g}$ of each sample was transferred to a $250 \mathrm{ml}$ Erlenmeyer flask, $100 \mathrm{ml}$ of distilled water was added to each flask, $25 \mathrm{ml}$ of $\mathrm{H}_{2} \mathrm{O}_{2}(30 \%)$ was added to each flask. The flasks were transferred to a water bath for heating up to $90^{\circ} \mathrm{C}$ for 2 days to destroy all the organic matter presents in the samples. After cooling the flasks, $7 \mathrm{ml}(1 \%)$ of $\mathrm{HCl}$ was added to each flask to destroy the $\mathrm{CaCO}_{3}$. After completing the $\mathrm{CaCO}_{3}$ degradation, the samples were transferred to a shaking bottles and $25 \mathrm{ml}$ of Na-pyrophosphate ( 0.4 molar) was added to each bottle. The bottles were sealed with a plastic device and shacked for $2 \mathrm{~h}$ using a rotary shaker to have a homogenized soil suspension. All chemicals used in this section were HPLC grade.

The suspension in the bottle was decanted into a series of sieves with the following diameters $(630,200,63$ and $20 \mu \mathrm{m})$ arranged from the top to the bottom. The sieves were mechanically shacked for 10 min under continues water flow. Then each sieve was separated for the series and its content was transferred to a glass container its weight in dry form was previously collected.

The containers were transferred to the oven for an overnight drying at $105^{\circ} \mathrm{C}$. In the next day the containers were weighed. The difference between the dry empty container and dry full container equal the weight of the soil particle separated in the sieves. Fraction \% was collected according to Equation (1) [19].

$$
\text { Fraction }=\frac{\text { weight of a fraction }}{\text { total weight of particles }} * 100
$$

\subsection{Hydraulic Conductivity Determination}

Each site was subdivided into four plots as follows: control plot (CP), and three disturbed plots (DP1, DP2, and DP3). The idea behind disturbing soil plots is to investigate the effect of disturbance on hydraulic conductivity. The differences among the three disturbed plots were in depth of disturbance. The disturbing depth was 3,5 and $10 \mathrm{~cm}$. These depths were manually achieved using special device of wood containing nails with the above mention lengths. The reason behind selecting these depths were to destroy the salt crust that may be formed in the top 3 and $5 \mathrm{~cm}$ due to sea water drift, whereas, and destroy soil large halls due to growth of earth worm.

Hydraulic conductivity in different soils was determined by Minidisk Infiltrometer (Decagon Devices, Inc. 2007-2017) [20]. On this method the Infiltrometer was placed on the top soil and measured the infiltrated amount of water in certain time (e.g., 30 second) then the measurements were repeated at least five times on the same location with different periods of time from those mentioned above. The time can be different of that mentioned above but it may be better to be attached to a certain time during the measurement.

With a slight modification of previous published work [21] [22], calculation of hydraulic conductivity required at least five readings in the same location. The 
time of the reading is constant and the volume of water may be changed due to hydraulic conductivity. Knowing the infiltrated water volume and diameter of the Infiltrometer enabled us to calculate the depth of water infiltration in soil. Plotting the relationship between the cumulative square root of time vs cumulative infiltration depth provided a polynomial mode of relationship. The slope of the polynomial mode indicates the hydraulic conductivity in the soil.

\subsection{Statistical Analysis of the Data}

Following to the procedure described in El-Nahhal et al. [19], means and standard deviation of data were calculated. t-test was used to determine significant differences among values in different soil profiles. p-value below 0.05 indicate significant difference and tested parameters.

\section{Results}

\subsection{Soil Profiles}

Soil profile photos are shown in Figure 1. Regardless to the differences in brightness of photos, the soil profiles are similar in color soil structure except site 2 (Bait Lahia) the soil seems to be compacted due to previous agricultural activity. So far, the differences in soil profile probably were due to time and weather during photos since the work was not achieved in the same day. The important data of the sites are summarized in Table 1. Nevertheless, the sites are different in rainfall, the highest one is Bait lahia (site 2) $433 \mathrm{~mm}$, and the lowest one is Rafah (sites 5 \& 6) $236 \mathrm{~mm}$.

\subsection{Particle Size Distributions}

Particle size distribution in all sites is shown in Table 2(a) and Table 2(b). It can be seen that the trend of particle size distribution is similar in all depths at any site. For instance the largest particle size, $630 \mu \mathrm{m}$, and the smallest particle size, $20 \mu \mathrm{m}$, represented the lowest fractions at any soil layer in the soil profile. On the other hand, the particle size $200 \mu \mathrm{m}$ and $63 \mu \mathrm{m}$ were the largest fractions at any soil layer in the soil profile.

Nevertheless, the average of each particle size in all layers at all soil profiles was presented in Figure 2. The trend of particle size distribution is similar in all soil profile. Statistical analysis showed significant differences of each particle size. It can be noticed that the fractions of the size $630 \mu \mathrm{m}$ are similar in all sites whereas the fractions of $200 \mu \mathrm{m}$ are similar in sites 2,3 and 4 and significantly different at sites 1 and 5. On the other hands the fraction of particle size $63 \mu \mathrm{m}$ are similar in sites 1 and 2 and significantly different on the other sites. Furthermore the fraction of $20 \mu \mathrm{m}$ is not significantly different in all sites except site 5. The data in Figure 2 were marked with different letters ( $a, b$ and $c$ ), where the statistical analysis indicated significant differences at p-value was less than 0.05.

Furthermore, it can be noticed that all soil profiles (Table 2(a), Table 2(b)) contained low fractions of the largest size $630 \mathrm{~mm}$ and fine particles $20 \mathrm{~mm}$. The 
majority of particle size is $200 \mathrm{~mm}$ followed by $63 \mathrm{~mm}$ in all soil profiles. These results indicated that the structure of soils in all sites were sandy and nearly similar. Furthermore, statistical analysis of the data in Figure 2 did not detect significant differences on the particle size $630 \mathrm{~nm}$ found in all sites whereas significant differences were detected on the fraction of $200 \mathrm{~nm}$ from all sites. It is obvious that sites 2, 3 and site 4 are nearly similar but are different from site 1 and site 5 . The interesting point here is the similarity on sites 3 and 4 suggesting no effects from the tree on particle size distribution. Moreover, differences were also detected on the fraction of $63 \mathrm{~nm}$ but sites 3 and 4 are nearly similar confirming no effects from the tree on particle size distribution.

Table 2. (a) Particles size distribution in sites 1 and 2. The data are presented in \%. (b) Particles size distribution in sites 3 - 5 . The data are presented in \%.

(a)

\begin{tabular}{|c|c|c|c|c|c|c|c|c|}
\hline \multirow{2}{*}{ Depth $(\mathrm{cm})$} & \multicolumn{4}{|c|}{ Khan Younis (Site 1) } & \multicolumn{4}{|c|}{ Bait Lahia (Site 2) } \\
\hline & $630 \mu \mathrm{m}$ & $200 \mu \mathrm{m}$ & $63 \mu \mathrm{m}$ & $20 \mu \mathrm{m}$ & $630 \mu \mathrm{m}$ & $200 \mu \mathrm{m}$ & $63 \mu \mathrm{m}$ & $20 \mu \mathrm{m}$ \\
\hline $0-10$ & 1.26 & 77.64 & 19.44 & 1.66 & 0.61 & 77.07 & 20.55 & 1.77 \\
\hline $10-20$ & 1.56 & 83.99 & 13.51 & 0.94 & 0.45 & 77.84 & 20.13 & 1.57 \\
\hline $20-30$ & 2.19 & 83.92 & 13.67 & 0.21 & 0.67 & 81.25 & 16.85 & 1.23 \\
\hline $30-40$ & 0.93 & 81.10 & 17.65 & 0.31 & 0.44 & 75.58 & 23.09 & 0.89 \\
\hline $40-50$ & 0.62 & 83.75 & 15.53 & 0.10 & 1.50 & 82.16 & 14.85 & 1.50 \\
\hline $50-70$ & 0.31 & 86.05 & 13.53 & 0.10 & 0.32 & 78.48 & 20.89 & 0.32 \\
\hline $70-90$ & 1.79 & 86.45 & 11.55 & 0.21 & 0.21 & 81.49 & 17.34 & 0.96 \\
\hline $90-110$ & 1.83 & 86.68 & 11.06 & 0.43 & 0.21 & 78.02 & 20.93 & 0.84 \\
\hline $110-130$ & 0.10 & 81.46 & 18.33 & 0.10 & 0.63 & 82.42 & 16.32 & 0.63 \\
\hline $130-150$ & 0.21 & 76.76 & 22.71 & 0.32 & 0.74 & 83.05 & 16.00 & 0.21 \\
\hline
\end{tabular}

(b)

\begin{tabular}{ccccccccccccc}
\hline Depth (cm) & \multicolumn{3}{c}{ Site 3 (under tree) 2011 } & \multicolumn{3}{c}{ Site 4 (3 meter away) 2011 } & \multicolumn{3}{c}{ Site 5 (Rafah) 2012} \\
\hline & $630 \mu \mathrm{m}$ & $200 \mu \mathrm{m}$ & $63 \mu \mathrm{m}$ & $20 \mu \mathrm{m}$ & $630 \mu \mathrm{m}$ & $200 \mu \mathrm{m}$ & $63 \mu \mathrm{m}$ & $20 \mu \mathrm{m}$ & $630 \mu \mathrm{m}$ & $200 \mu \mathrm{m}$ & $63 \mu \mathrm{m}$ & $20 \mu \mathrm{m}$ \\
\hline $0-10$ & 0.24 & 76.10 & 14.03 & 1.07 & 0.08 & 75.41 & 15.44 & 1.66 & 1.04 & 88.91 & 4.64 & 5.41 \\
$10-20$ & 0.2 & 77.54 & 14.3 & 0.64 & 0.21 & 68.28 & 19.54 & 2.37 & 0.03 & 79.13 & 13.94 & 6.90 \\
$20-30$ & 0.32 & 76.54 & 14.37 & 1.23 & 0.47 & 80.68 & 9.76 & 0.75 & 0.01 & 87.49 & 6.02 & 6.48 \\
$30-40$ & 0.38 & 76.17 & 13.74 & 1.86 & 0.3 & 70.44 & 18.72 & 1.65 & 0.07 & 89.42 & 4.38 & 6.13 \\
$40-50$ & 0.26 & 78.54 & 11.98 & 0.69 & 0.16 & 78.5 & 13 & 0.49 & 0.04 & 87.67 & 5.08 & 7.20 \\
$50-70$ & 0.28 & 77.26 & 13.56 & 0.41 & 0.12 & 81.79 & 9.28 & 0.41 & 0.02 & 91.79 & 1.52 & 6.66 \\
$70-90$ & 0.56 & 81.63 & 9.6 & 0.7 & 0.36 & 76.18 & 13.79 & 1.2 & 0.09 & 82.04 & 1.31 & 16.56 \\
$90-110$ & 0.21 & 75.17 & 16.57 & 0.37 & 0.43 & 82.33 & 9.83 & 0.8 & 0.07 & 91.81 & 6.02 & 2.10 \\
$110-130$ & 0.21 & 75.61 & 15.09 & 0.92 & 0.2 & 83.57 & 8.88 & 0.92 & 0.14 & 94.29 & 0.81 & 4.76 \\
$130-150$ & 0.1 & 83.01 & 11.53 & 0.27 & 0.07 & 77.12 & 12.88 & 1.55 & 0.08 & 95.23 & 0.75 & 3.94 \\
\hline
\end{tabular}




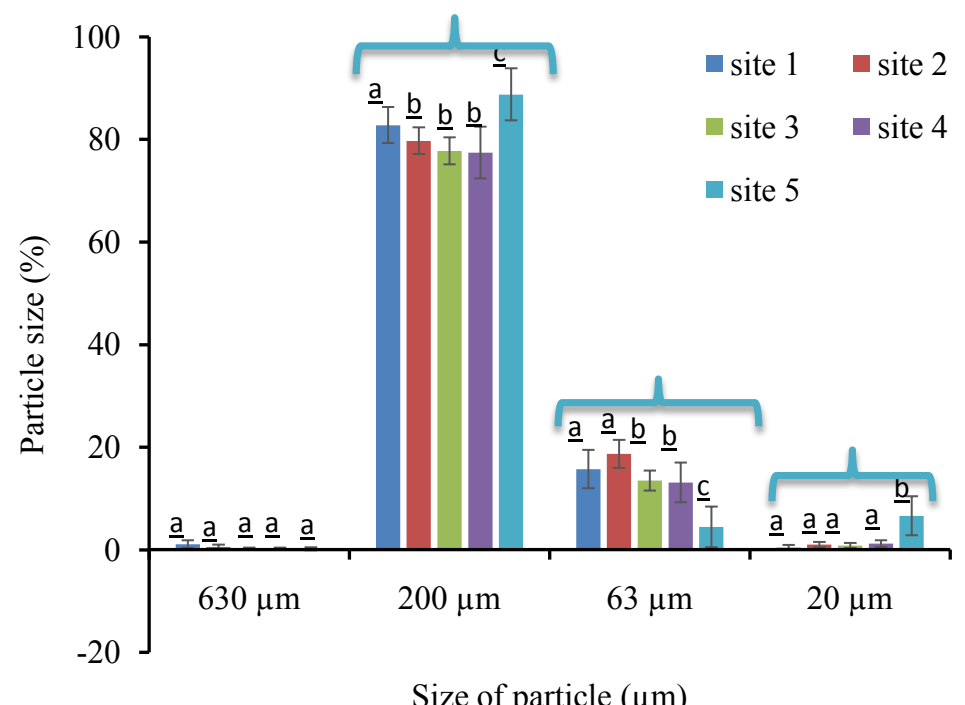

Figure 2. Particle size distribution (mean \pm standard derivation) in all soil depths of soil profiles in different sites. Error bars represent standard deviations. Columns have the same letter $(a, b$, or $c)$ at any particle size are not significantly different at $\mathrm{p}$-value $=0.05$.

\subsection{Hydraulic Conductivity}

Hydraulic conductivity $(\mathrm{Kc})$ of the soil profiles and surrounding areas are shown in Table 3. It can be noticed that the Kc values are different in the same testing site due to the disturbance depth of soil. So far, in site $1, \mathrm{Kc}$ value is the smallest in the control plot soil (CP, soil was not disturbed), whereas the values of Kc in the disturbed plots are several times higher. On the other hand, Kc values are quite similar in site 2 .

Furthermore, SH.E DP3 has the highest Kc value in site 3 whereas Rafah DP2 has the lowest value in site 4 . These differences reflect the differences in pore size distribution in the tested soil. Nevertheless, the high value of regression coefficient (R2) indicates the precision of the presented results.

\section{Discussion}

The studied land is a coastal non-agricultural land has a wide range of rainfall gradient $(290-450 \mathrm{~mm})$. The studied sites have no agricultural activity in the surrounding area for the past ten years. In general Gaza strip is considered as a semi-arid zone due to the lack of rainfall during the year. The data in Table 1 clearly shows important information of the tested soil profiles.

The data in Table 2 clearly shows the fractions of particle size in each soil layer of the soil profiles. It is obvious that the fractions of $630 \mathrm{~nm}$ and $20 \mathrm{~nm}$ are nearly low fractions in all sites, whereas the fraction of $200 \mathrm{~nm}$ is the dominant particle size in all sites followed by the fraction $63 \mathrm{~nm}$. Statistical analysis did not detect significant differences in the particles size of $630 \mathrm{~nm}$ in all sites whereas significant differences were found in other fractions. These data suggest that the sites were exposed to similar weathering conditions along the coastal plain in Gaza Strip. This explanation agrees with Michel et al. [23] who revealed the in- 
fluence of weathering conditions on soil particle size distribution. Additionally, the locations of the soil profiles are in the coastal plain of Gaza strip (Figure 1), where sands can be transferred from the coastal area to the urban area due to water movements and wend circulations, consequently similar particle size would have accumulated in the sites. Moreover, it can be suggested that differences in wind storm intensity may have resulted in different sand flow or creeping rates in the sites resulting in differences in the particle size distribution along the coastal plain. This suggestion is supported by experimental works of Bełdowska [24] who reported the influence of weather anomalies on metal cycling in the marine coastal zone of the southern Baltic.

An interesting outcome here is that the similarity in the fraction size $630 \mu \mathrm{m}$ in all sites and similarity in fraction size $20 \mu \mathrm{m}$ except site 5 . On the other hands the fraction $200 \mu \mathrm{m}$ is similar in sites 2,3 , and 4 . This suggests similar weathering conditions in the corresponding sites.

Furthermore, the dominant particle size $200 \mathrm{~nm}$ in all sites suggests the formation of large pore size in soil structure consequently water movement in soil would strongly be affected by this fraction. This agrees with El-Nahhal et al. [25], who found high water movement in sandy soil with large particle size. In addition, wide range of particle size in soil may have ecological benefits such as enhancing water movement in soil enriching the ground water aquifer, affect sorption and desorption behaviors of steroid hormones [26], affect the distribution of heavy metals [27] [28]. Furthermore, it can be suggested that various particle size fractions in soil profile may create specific porous size that suit the colonization and the activity of soil microorganisms. This suggestion is in accordance with Hemkemeyer et al., [29] who demonstrated that the mineral composition and the particle size fractions in soil have specific and different selective effects on the abundance and diversity of Bacteria, Archaea and Fungi in natural soils with complex mineral compositions.

In addition, the dominancy fraction size $200 \mathrm{~nm}$ all sites followed by the fraction $63 \mathrm{~nm}$ suggests the formation of similar pore size in soil that can affect the hydraulic conductivity in soil. This suggestion is supported by the values of Kc presented in Table 3, regardless to the fact that Kc values in Table 3 are not equal.

However, the variations in Kc values in Table 3 can be explained by the differences in disturbing depth and differences in rainfall during the year (Table 1). This explanation is in accordance with Armenise et al. [15] who investigated influence of rainfall in the hydraulic conductivity and found two different trends in soil porosity vs. depth. Moreover, high rainfall may result in leaching and washing of salts from the top soil to deeper depths. This increases the free movement of water molecules in soil profile. This is in accordance with El-Nahhal and Safi [30] [31] who revealed the influence of salinity in the free water molecules to dissolve organic cations.

Furthermore, land use and land cover may affect the hydraulic conductivity in 
soils as seen in (Table 2) in the control plot soils and disturbed plot soils. This assumption agrees with Wong et al. [16] who reported that biochar application increased the saturated hydraulic conductivity of compacted clay, and the increment was positively correlated to the biochar percentage. Additionally, the similarity in Kc values in site 2, probably due to the compaction of soil as seen in photos in Figure 1 and similarity in particle size distribution (Figure 2).

\section{Comparisons with Previous Published Work}

A comparison between the present study and those from the literature is presented in Table 4. It is obvious that the present study deals with a coastal

Table 3. Hydraulic conductivity and regression parameters in different soils.

\begin{tabular}{ccccc}
\hline Site \# & Site name & Kc & Regression Eq & R2 \\
\hline \multirow{2}{*}{1} & Kh CP & 0.27 & $Y=0.0291 X^{2}+0.0665 X$ & 0.9725 \\
& Kh DP1 & 1.7 & $Y=0.2184 X^{2}+0.1784 X$ & 0.9993 \\
& Kh DP2 & 1.42 & $Y=0.2264 X^{2}+0.1603 X$ & 0.9997 \\
& Kh DP3 & 1.35 & $Y=0.1748 X^{2}+0.1336 X$ & 0.9991 \\
& BL CP & 0.33 & $Y=0.0118 X^{2}+0.2505 X$ & 0.9879 \\
& BL DP1 & 0.36 & $Y=0.0575 X^{2}-0.04 X$ & 0.9958 \\
& BL DP2 & 0.27 & $Y=0.0479 X^{2}-0.0563 X$ & 0.9791 \\
& BL DP3 & 0.37 & $Y=0.0774 X^{2}-0.172 X$ & 0.9835 \\
\hline \multirow{3}{*}{3} & SH.E CP1 & 0.67 & $Y=0.1439 X^{2}-0.3222 X$ & 0.994 \\
& SH.E DP1 & 0.56 & $Y=0.1449 X^{2}-0.3507 X$ & 0.9992 \\
& SH.E DP2 & 0.61 & $Y=0.0876 X^{2}+0.003 X$ & 0.9988 \\
& SH.E DP3 & 1.76 & $Y=0.252 X^{2}+0.0052 X$ & 0.9997 \\
& Rafah CP1 & 1.19 & $Y=0.1815 X^{2}-0.0783 X$ & 0.9971 \\
& Rafah DP1 & 1.16 & $Y=0.1529 X^{2}+0.0972 X$ & 0.9996 \\
& Rafah DP2 & 0.64 & $Y=0.0875 X^{2}+0.033 X$ & 0.9895 \\
& Rafah DP3 & 1.44 & $Y=0.1951 X^{2}+0.0878 X$ & 0.9979 \\
\hline
\end{tabular}

CP, DP1-3, are control plot soil and disturbed plot soil. $Y$ and $X$ are cumulative infiltration depth $(\mathrm{cm})$ and square root of time respectively.

Table 4. Comparing parameters with other works.

\begin{tabular}{cccccc}
\hline Tested Parameter & This study & $\begin{array}{c}\text { Farhangi } \text { et al. } \\
{[32]}\end{array}$ & $\begin{array}{c}\text { Venancio et al. } \\
{[33]}\end{array}$ & $\begin{array}{c}\text { Wang et al. } \\
{[34]}\end{array}$ & $\begin{array}{c}\text { Filipović et al. } \\
{[35]}\end{array}$ \\
\hline $\begin{array}{c}\text { Particle size } \\
\text { Hydraulic } \\
\text { conductivity }\end{array}$ & $\sqrt{3}$ & - & - & - & $\sqrt{ }$ \\
Soil type & Coastal plain & Agriculture & Forest & Wetland & Agriculture \\
Salinity & - & - & $\sqrt{ }$ & $\sqrt{ }$ & $\sqrt{ }$ \\
$\mathrm{CaCO}_{3}$ & - & $\sqrt{ }$ & - & - & $\sqrt{ }$ \\
\hline
\end{tabular}


non-agricultural land and determined important soil parameters that were useful of agricultural and non-agricultural lands. Published work [32] [33] [34] [35] dealt with agricultural, forest and wetlands and determined few parameters of soils such salinity. The previous published works were localized to certain small study site whereas the present study digged several soil profiles along a distance of $45 \mathrm{~km}$. Moreover, the present study provided data on particles size distribution, hydraulic conductivity of different soil plots whereas other studies [32] [35] evaluated carbonate concentrations in top soil layers. Additionally, the previous studies partially determined the salinity in soil, whereas the present study focused here on particle size and hydraulic conductivity. It can be concluded that the present study integrated the picture by determining the particle size and hydraulic conductivity in non-agricultural land. So that this study is opining a new window of investigation toward land reclamation and land use.

\section{Environmental Relevance}

Environmental relevance of this work emerged from the fact that particles size in soil fraction has specific surface area that plays an important role in the chemical fate of organic and inorganic molecules. For instance, the smallest particle size the largest surface area that can absorb organic cations [36] [37] [38] and create a hydrophobic zone [39] that can absorb organic contaminants from water. Moreover, diversity of pore size may be created and can be a suitable habitat for soil cyanobacteria that can biodegrade organic molecules and remediate soil pollution [3] [40]. Recent development [25] in wastewater treatment used different particle size of sand for optimizing efficacy of sand filter.

\section{Significance of This Work}

Significance of this work emerged from the fact that it is the first time that coastal nonagricultural land being investigated for particle size distribution and hydraulic conductivity measurements in Palestine and surrounding countries. The unique point of this work is that the data will be available for the scientific community in the world for comparison or following technical procedure. Moreover, the information of this study can be of great importance to the researchers in desert lands, lands under reclamation agricultural land and/or wet lands. Furthermore, the new theory that will be arrived from this work is that soils are different and sensitive to different environmental factors that may affect the soil properties.

\section{Conclusion}

The rational of this work emerged from the fact that it is the first time along the coastal plain in Gaza Strip that soil profiles were digged in non-agricultural land to determine particle size distribution and hydraulic conductivity. Soil particles size analysis demonstrated that the dominancy of fraction $200 \mu \mathrm{m}$ in all sites followed by the fraction $63 \mathrm{~nm}$. The hydraulic conductivity was affected by dis- 
turbance depth of the tested soil.

\section{Author's Contribution}

JS designed the experimental work and revised the manuscript. YE did the laboratory experiments and wrote the manuscript. MS did the field work and data collection and statistically analyzed the experimental data.

\section{Acknowledgements}

The work was funded by Dousche Forshoung Gemanshaft (DFG) Germany, grant DFG: Fe 218 13/1 Special thanks go to Prof Dr Peter Felxhenengssen, at Gessen University.

\section{Conflicts of Interest}

The authors declare no conflicts of interest regarding the publication of this paper.

\section{References}

[1] El-Nahhal, I., Al-Najar, H. and El-Nahhal, Y. (2014) Cations and Anions in Sewage Sludge from Gaza Waste Water Treatment Plant. American Journal of Analytical Chemistry, 5, 655-665. https://doi.org/10.4236/ajac.2014.510073

[2] El-Nahhal, I., Al-Najar, H. and El-Nahhal, Y. (2014) Physicochemical Properties of Sewage Sludge from Gaza. International Journal of Geosciences, 5, 586-594. https://doi.org/10.4236/ijg.2014.56053

[3] Safi, J., Awad, Y. and El-Nahhal, Y. (2014) Bioremediation of Diuron in Soil and by Cyanobacterial Mat. American Journal of Plant Sciences, 5, 1081-1089. https://doi.org/10.4236/ajps.2014.58120

[4] El-Nahhal, Y., Nir, S., Serban, C., Rabinowitz, O. and Rubin, B. (2000) Montmorillonite-Phenyltrimethylammounium Yields Environmentally Improved Formulations of Hydrophobic Herbicides. Journal of Agricultural and Food Chemistry, 48, 4791-4801. https://doi.org/10.1021/jf000327j

[5] Qian, J., Shan, X.Q., Wang, Z.J. and Tu, Q. (1996) Distribution and Plant availability of Heavy Metals in Different Particle-Size Fractions of Soil. Science of the Total Environment, 187, 131-141. https://doi.org/10.1016/0048-9697(96)05134-0

[6] Rodriguez-Rubio, P., Morillo, E., Madrid, L., Undabeytia, T. and Maqueda, C. (2003) Retention of Copper by Calcareous Soil and Its Textural Fractions: Influence of Amendment with Two Agroindustrial Residues. European Journal of Soil Science, 54, 401-409. https://doi.org/10.1046/j.1365-2389.2003.00529.x

[7] Lin, Z.X., Harsbo, K., Ahlgren, M. and Qvarfort, U. (1998) The Source and Fate of $\mathrm{Pb}$ in Contaminated Soils at the Urban Area of Falun in Central Sweden. Science of the Total Environment, 209, 47-58. https://doi.org/10.1016/S0048-9697(97)00300-8

[8] Ho, K.F., Lee, S.C., Chow, J.C. and Watson, J.G. (2003) Characterization of $\mathrm{PM}_{10}$ and $\mathrm{PM}_{2.5}$ Source Profiles for Fugitive Dust in Hong Kong. Atmospheric Environment, 37, 1023-1032. https://doi.org/10.1016/S1352-2310(02)01028-2

[9] Lee, P.K., Yu, Y.H., Yun, S.T. and Mayer, B. (2005) Metal Contamination and Solid Phase Partitioning of Metals in Urban Roadside Sediments. Chemosphere, 60, 672-689. https://doi.org/10.1016/j.chemosphere.2005.01.048 
[10] Bird, N.R.A., Preston, A.R., Randall, E.W., Whalley, W.R. and Whitmore, A.P. (2005) Measurement of the Size Distribution of Water-Filled Pores at Different Matric Potentials by Stray Field Nuclear Magnetic Resonance. European Journal of Soil Science, 56, 135-143. https://doi.org/10.1111/j.1351-0754.2004.00658.x

[11] Bachmann, J., Horn, R. and Peth, S. (2014) Einfuhrung in die Bodenphysik. https://www.schweizerbart.de/publications/detail/isbn/9783510652808

[12] Bayer, J.V., Jaeger, F. and Schaumann, G.E. (2010) Proton Nuclear Magnetic Resonance (NMR) Relaxometry in Soil Science Applications. The Open Magnetic Resonance Journal, 3, 15-26. https://doi.org/10.2174/1874769801003010015

[13] Trinh, T., Kavvas, M.L., Ishida, K., Ercan, A., Chen, Z.Q., Anderson, M.L., Ho, C. and Nguyen, T. (2018) Integrating Global Land-Cover and Soil Datasets to Update Saturated Hydraulic Conductivity Parameterization in Hydrologic Modeling. Science of the Total Environment, 631-632, 279-288.

https://doi.org/10.1016/j.scitotenv.2018.02.267

[14] Pineda, M.C., Viloria, J., Martínez-Casasnovas, J.A., Valera, A., Lobo, D., Timm, L.C., Pires, L.F. and Gabriels, D. (2018) Predicting Soil Water Content at $-3 \mathrm{kPa}$ by Pedotransfer Functions in Stoniness 1 Soils in northeast Venezuela. Environmental Monitoring and Assessment, 190, 161. https://doi.org/10.1007/s10661-018-6528-3

[15] Armenise, E., Simmons, R.W., Ahn, S., Garbout, A., Doerr, S.H., Mooney, S.J., Sturrock, C.J. and Ritz, K. (2018) Soil Seal Development under Simulated Rainfall: Structural, Physical and Hydrological Dynamics. Journal of Hydrology, 556, 211-219. https://doi.org/10.1016/j.jhydrol.2017.10.073

[16] Wong, J.T.F., Chen, Z., Wong, A.Y.Y., Ng, C.W.W. and Wong, M.H. (2018) Effects of Biochar on Hydraulic Conductivity of Compacted Kaolin Clay. Environmental Pollution, 234, 468-472. https://doi.org/10.1016/j.envpol.2017.11.079

[17] Neumann, D., Heuer, A., Hemkemeyer, M., Martens, R. and Tebbe, C.C. (2013) Response of Microbial Communities to Long-Term Fertilization Depends on Their Microhabitat. FEMS Microbiology Ecology, 86, 71-84. https://doi.org/10.1111/1574-6941.12092

[18] Amelung, W., Zech, W., Zhang, X., Follett, R.F., Tiessen, H., Knox, E. and Flach, K.W. (1998) Carbon, Nitrogen, and Sulfur Pools in Particle-Size Fractions as Influenced by Climate. Soil Science Society of America Journal, 62, 172-181. https://doi.org/10.2136/sssaj1998.03615995006200010023x

[19] El-Nahhal, Y., Safi, M., Tubail, K. and Safi, J. (2013) Effect of Treated Wastewater Irrigation on Plant Growth and Soil Properties in Gaza Strip Palestine. American Journal of Plant Science, 4, 1736-1743. https://doi.org/10.4236/ajps.2013.49213

[20] Zhang, R. (1997) Determination of Soil Sorptivity and Hydraulic Conductivity from the Disk Infiltrometer. Soil Science Society of America Journal, 61, 1024-1030. https://doi.org/10.2136/sssaj1997.03615995006100040005x

[21] Dane, J.H. and Topp, G.C. (2002) Methods of Soil Analysis Part 4-Physical Methods. Soil Science Society of America, Madison.

[22] Dohnal, M., Dusek, J. and Vogel, T. (2010) Improving Hydraulic Conductivity Estimates from Minidisk Infiltrometer Measurements for Soils with Wide Pore-Size Distributions. Soil Science Society of America Journal, 74, 804-811. https://doi.org/10.2136/sssaj2009.0099

[23] Michel, F.M., Barrón, V., Torrent, J., Morales, M.P., Serna, C.J., Boily, J.F., Liu, Q., Ambrosini, A., Cismasu, A.C. and Brown, G.E. (2010) Ordered Ferrimagnetic Form of Ferrihydrite Reveals Links among Structure, Composition, and Magnetism. Proceedings of the National Academy of Sciences, 107, 2787-2792. 
https://doi.org/10.1073/pnas.0910170107

[24] Bełdowska, M. (2015) The Influence of Weather Anomalies on Mercury Cycling in the Marine Coastal Zone of the Southern Baltic-Future Perspective. Water, Air, \& Soil Pollution, 226, 2248. https://doi.org/10.1007/s11270-014-2248-7

[25] El-Nahhal, Y., El-Dahdouh, O. and Anajjar, H. (2017) Influence of Sand Filter in Waste-Water Treatment (a Case Study in Gaza City, Gaza Strip Wastewater Treatment Plant). Desalination and Water Treatment, 89, 118-126. https://doi.org/10.5004/dwt.2017.21398

[26] Qi, Y., Zhang, T.C. and Ren, Y. (2014) Testosterone Sorption and Desorption: Effects of Soil Particle Size. Journal of Hazardous Materials, 279, 493-501. https://doi.org/10.1016/j.jhazmat.2014.06.077

[27] Li, Q., Ji, H., Qin, F., Tang, L., Guo, X. and Feng, J. (2014) Sources and the Distribution of Heavy Metals in the Particle Size of Soil Polluted by Gold Mining Upstream of Miyun Reservoir, Beijing: Implications for Assessing the Potential Risks. Environmental Monitoring and Assessment, 186, 6605-6626. https://doi.org/10.1007/s10661-014-3877-4

[28] Ayoubi, S., Soltani, Z. and Khademi, H. (2018) Particle Size Distribution of Heavy Metals and Magnetic Susceptibility in an Industrial Site. Bulletin of Environmental Contamination and Toxicology, 100, 708-714. https://doi.org/10.1007/s00128-018-2316-6

[29] Hemkemeyer, M., Pronk, G.J., Heister, K., Kögel-Knabner, I., Martens, R. and Tebbe, C.C. (2014) Artificial Soil Studies Reveal Domain-Specific Preferences of Microorganisms for the Colonisation of Different Soil Minerals and Particle Size Fractions. FEMS Microbiology Ecology, 90, 770-782. https://doi.org/10.1111/1574-6941.12436

[30] El-Nahhal, Y. and Safi, J. (2004) Adsorption Behavior of Phenanthrene on Organoclays under Different Salinity Levels. Journal of Colloid and Interface Science, 269, 265-273. https://doi.org/10.1016/S0021-9797(03)00607-6

[31] El-Nahhal, Y. and Safi, J. (2004) Stability of an Organo Clay Complex: Effects of High Concentrations of Sodium Chloride. Applied Clay Science, 24, 129-136. https://doi.org/10.1016/j.clay.2003.01.002

[32] Farhangi, M.B., Safari Sinegani, A.A., Mosaddeghi, M.R., Uncc, A. and Khodakaramian, G. (2013) Impact of Calcium Carbonate and Temperature on Survival of Escherichia Coli in Soil. Journal of Environmental Management, 119, 13-19. https://doi.org/10.1016/j.jenvman.2013.01.022

[33] Venancio, C., Pereira, R., Freitas, A.C., Rocha-Santos, T.A.P., da Costa, J.P., Duarte, A.C. and Lopes, I. (2017) Salinity Induced Effects on the Growth Rates and Mycelia Composition of Basidiomycete and Zygomycete Fungi. Environmental Pollution, 231, 1633-1641. https://doi.org/10.1016/j.envpol.2017.09.075

[34] Wang, X., Zhang, F., Ding, J., Kung, H., Latif, A. and Johnson, C.V. (2018) Estimation of Soil Salt Content (SSC) in the Ebinur Lake Wetland National Nature Reserve (ELWNNR), Northwest China, Based on a Bootstrap-BP Neural Network Model and Optimal Spectral Indices. Science of the Total Environment, 615, 918-930. https://doi.org/10.1016/j.scitotenv.2017.10.025

[35] Filipović, L., Romić, M., Romić, D., Filipović, V. and Ondrašek, G. (2018) Organic Matter and Salinity Modify Cadmium Soil (Phyto) Availability. Ecotoxicology and Environmental Safety, 147, 824-831. https://doi.org/10.1016/j.ecoenv.2017.09.041

[36] El-Nahhal, Y., Nir, S., Polubesova, T., Margulies, L. and Rubin, B. (1998) Leaching, Phyto-Toxicity and Weed Control of New Formulations of Alachlor. Journal of 
Agricultural Food Chemistry, 46, 3305-3313. https://doi.org/10.1021/jf971062k

[37] El-Nahhal, Y., Nir, S., Polubesova, T., Margulies, L. and Rubin, B. (1999) Movement of Metolachlor in Soil: Effect of Organo-Clay Formulation. Pesticide Science, 55, 857-864.

https://doi.org/10.1002/(SICI)1096-9063(199908)55:8<857::AID-PS24>3.0.CO;2-P

[38] Nir, S., Undabeytia, T., Yaron, D., El-Nahhal, Y., Polubesova, T., Serban, S., Rytwo, G., Lagaly, G. and Rubin, B. (2000) Optimization of Adsorption of Hydrophobic Herbicides on Montmorillonite Preadsorbed by Monovalent Organic Cations: Interaction between Phenyl Rings. Environmental Science and Technology, 34, 1269-1274. https://doi.org/10.1021/es9903781

[39] Jaynes, F.W. and Boyd, A.S. (1992) Trimethylphenylammonium-Smectite as an Effective Adsorbent of Water Soluble Aromatic Hydrocarbons. Journal of the Air Waste Management Association, 40, 1649-1653.

[40] El-Nahhal, Y., Awad, Y. and Safi, J. (2013) Bioremediation of Acetochlor in Soil and Water Systems by Cyanobacterial Mat. International Journal of Geosciences, 4, 880-890. https://doi.org/10.4236/ijg.2013.45082 